\title{
Diatom teratologies as biomarkers of contamination: Are all deformities ecologically meaningful?
}

\author{
Isabelle Lavoie $^{\mathrm{a}, *}$, Paul B. Hamilton ${ }^{\mathrm{b}}$, Soizic Morin ${ }^{\mathrm{c}}$, Sandra Kim Tiam ${ }^{\mathrm{a}, \mathrm{d}}$, Maria Kahlert ${ }^{\mathrm{e}}$, \\ Sara Gonçalves ${ }^{\mathrm{e}, \mathrm{f}}$, Elisa Falasco ${ }^{\mathrm{g}}$, Claude Fortin ${ }^{\mathrm{a}}$, Brigitte Gontero ${ }^{\mathrm{h}}$, David Heudre ${ }^{\mathrm{i}}$, \\ Mila Kojadinovic-Sirinelli ${ }^{\mathrm{h}}$, Kalina Manoylov ${ }^{\mathrm{j}}$, Lalit K. Pandey ${ }^{\mathrm{k}}$, Jonathan C. Taylor ${ }^{1, \mathrm{~m}}$ \\ a Institut National de la Recherche Scientifique, Centre Eau Terre Environnement, 490 rue de la Couronne, G1K 9A9, Québec (QC), Canada \\ b Phycology Section, Collections and Research, Canadian Museum of Nature, P.O. Box 3443, Station D, Ottawa, K1P 6P4 Ontario, Canada \\ ' Irstea, UR EABX, 50 Avenue de Verdun, 33612 Cestas Cedex, France \\ d Molécules de communication et adaptation des microorganismes, Cyanobactéries, Cyanotoxines et Environnement, Muséum National d'Histoire Naturelle, 12 rue Buffon, \\ F-75231 Paris, Cedex 05, France \\ e Swedish University of Agricultural Sciences, Department of Aquatic Sciences and Assessment, P.O. Box 7050, SE- 75007 Uppsala, Sweden \\ ${ }^{\mathrm{f}}$ Departamento de Biologia, Universidade de Aveiro. Campus de Santiago, 3810-193 Aveiro, Portugal \\ ${ }^{g}$ Department of Life Sciences and Systems Biology, University of Turin, via Accademia Albertina 13, 10123 Turin, Italy \\ h Aix Marseille Univ, CNRS, BIP, UMR 7281, IMM, 31 Chemin J. Aiguier, 13402 Marseille Cedex 20, France \\ ${ }^{i}$ DREAL Grand Est/Service Eau, Biodiversité et Paysage/Laboratoire d'hydrobiologie, 14 Rue du Bataillon de Marche $n^{\circ} 24,67200$ Strasbourg, France \\ ${ }^{\mathrm{j}}$ Department of Biological and Environmental Sciences, Georgia College and State University, Milledgeville, GA, 31061, USA \\ ${ }^{\mathbf{k}}$ Institute of Green Environmental Research, Incheon National University, 119, Academy-ro, Yeonsu-gu, 22012 Incheon, Republic of Korea \\ ${ }^{1}$ Unit for Environmental Sciences and Management, North-West University, P Bag X6001, 2520 Potchefstroom, South Africa \\ m South African Institute for Aquatic Biodiversity (SAIAB), P Bag 1015, 6140 Grahamstown, South Africa
}

\section{A R T I C L E I N F O}

\section{Keywords:}

Bioassessment

Biomarker

Contaminants

Deformities

Diatoms

Teratologies

\begin{abstract}
A B S T R A C T
Contaminant-related stress on aquatic biota is difficult to assess when lethal impacts are not observed. Diatoms, by displaying deformities (teratologies) in their valves, have the potential to reflect sub-lethal responses to environmental stressors such as metals and organic compounds. For this reason, there is great interest in using diatom morphological aberrations in biomonitoring. However, the detection and mostly the quantification of teratologies is still a challenge; not all studies have succeeded in showing a relationship between the proportion of abnormal valves and contamination level along a gradient of exposure. This limitation in part reflects the loss of ecological information from diatom teratologies during analyses when all deformities are considered. The type of deformity, the severity of aberration, species proneness to deformity formation, and propagation of deformities throughout the population are key components and constraints in quantifying teratologies. Before a metric based on diatom deformities can be used as an indicator of contamination, it is important to better understand the "ecological signal" provided by this biomarker. Using the overall abundance of teratologies has proved to be an excellent tool for identifying contaminated and non-contaminated environments (presence/absence), but refining this biomonitoring approach may bring additional insights allowing for a better assessment of contamination level along a gradient. The dilemma: are all teratologies significant, equal and/or meaningful in assessing changing levels of contamination? This viewpoint article examines numerous interrogatives relative to the use of diatom teratologies in water quality monitoring, provides selected examples of differential responses to contamination, and proposes solutions that may refine our understanding and quantification of the stress. This paper highlights the logistical problems associated with accurately evaluating and interpreting teratologies and stimulates more discussion and research on the subject to enhance the sensitivity of this metric in bioassessments.
\end{abstract}

\section{Introduction}

Diatoms are useful tools in the bioassessment of freshwater ecosystem integrity and are presently included in numerous water quality monitoring programs worldwide. A variety of diatom-based indices have been developed using different approaches (e.g., Lavoie et al., 2006, 2014 and references therein; Smol and Stoermer, 2010 and references therein). Most indices were created to assess ecosystem health

\footnotetext{
* Corresponding author.

E-mail address: ilavoie.bio@gmail.com (I. Lavoie).
} 


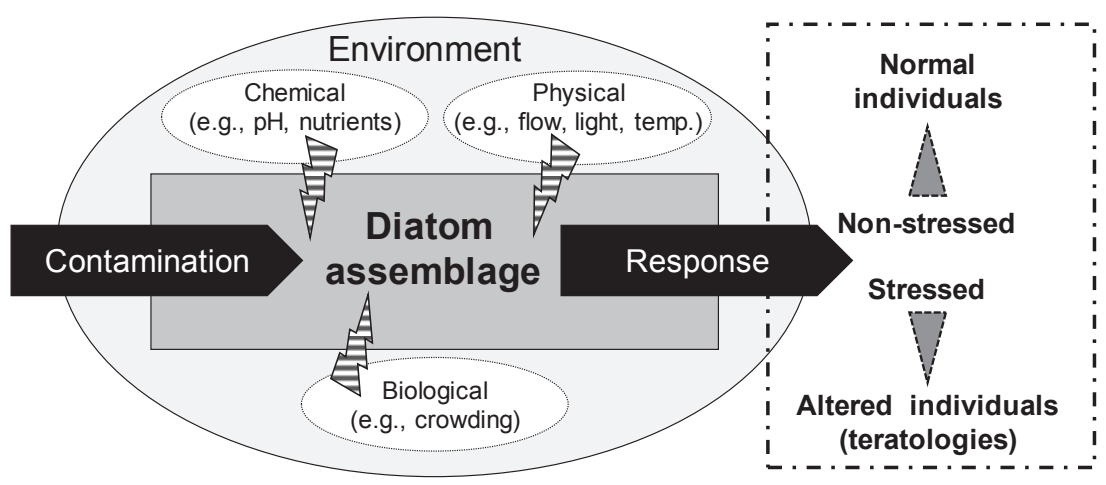

Fig. 1. Conceptual model representing the response of a diatom assemblage to environmental and anthropogenic perturbations.

reflecting general water quality and regional climate. There are also countless studies reporting the response of diatom assemblages to metal contamination (see review in Morin et al., 2012) and to organic contaminants (Debenest et al., 2010). However, diatom-based indices have not been developed to directly assess toxic contaminants (e.g., metals, pesticides, hydrocarbons). Contaminant-related stress on biota is difficult to assess when lethal impacts are not observed. Diatoms, by displaying aberrations in their valves (deviation from normal shape or ornamentation), have the potential to reflect sub-lethal responses to environmental stressors including contaminants. Observed deformities can affect the general shape of the valve, the sternum/raphe, the striation pattern, and other structures, or can be a combination of various alterations (Falasco et al., 2009a). Other stressors such as excess light, nutrient depletion, and low $\mathrm{pH}$ also have the potential to induce frustule deformities (Fig. 1; see review in Falasco et al., 2009a). However, the presence of abnormal frustules (also called teratologies or deformities) in highly contaminated environments is generally a response to toxic chemicals. For this reason, there is great interest in using morphological aberrations in biomonitoring. Teratologies may be a valuable tool to assess ecosystem health and it can be assumed that their frequency and severity are related to magnitude of the stress. We focussed our main discussion on teratologies as biomarkers although other descriptors such as valve densities, species diversity and assemblage structure are also commonly used to evaluate the response of diatom assemblages to contaminants.

Based on the current literature, the presence of deformities in contaminated environments is considered an indication of stress; however, detection and quantification of teratologies is still a challenge. In other words, not all studies have succeeded in showing a relationship between the proportion of abnormal valves and contamination level along a gradient of exposure (see Sections 3.2 and 5.1 for examples). Before a metric based on diatom teratologies can be used as an indicator of contamination, we believe it is imperative to better understand the "ecological information" provided by the different types of deformities and their severity. Furthermore, how are teratologies passed through generations of cell division? These aspects may influence our assessment and interpretation of water quality.

This paper will not provide a detailed review of the abundant literature on the subject of diatom valve morphogenesis or the different types of teratologies and their causes, but will examine numerous interrogatives relative to the use of diatom teratologies for the assessment of various types of contamination. This work is an extension of the discussion issued from the collaborative poster entitled "Diatom teratologies in bioassessment and the need for understanding their significance: are all deformities equal?" presented at the 24th International Diatom Symposium held in Quebec City (August 2016). The participants were invited to take part in the project by adding comments, questions and information directly on the poster board, and by collaborating on the writing of the present paper. Numerous questions were presented (Table 1) related to the indicator potential of different types of deformities and their severity, the transmission of teratologies as cells divide,
Table 1

List of questions that initiated this communication as well as questions raised by participants during the 24th International Diatom Symposium (IDS 2016, Quebec City).

Teratology formation and transmission

- How are deformities transmitted to the subsequent generations?

- The newly-formed valve is an exact copy (or smaller) of the mother cell; in this case, how does the first deformity of the valve outline appear?

- Are abnormal ornamentation patterns observed on both valves?

- Are deformed cells able to survive and reproduce?

Ecological meaning

- Are deformities equal between different species? Are all types of deformities equal within the same species?

- Are all toxicants likely to induce similar deformities? (or are deformities toxicantspecific?)

- Should a deformity observed on a "tolerant" species (versus a "sensitive" species) have more weight as an indicator of stress?

Issues with teratology assessment

- Certain types of deformities are difficult or impossible to see under a light microscope, particularly for small species. Should problematic taxa be included in bioassessments based on teratologies?

- How to assess deformities on specimen that are in girdle view?

- How should the "severity" of a teratology be assessed?

Implications for biomonitoring

- The sternum is the initial structure to be formed; should an abnormal sternum (including the raphe) be considered more important/significant than other types of aberrations?

- Proneness to produce abnormal valves and sensitivity to specific contaminants are key factors for the inclusion of teratological forms in diatom indices. How to quantify them?

- What is the significance of deformities in a single species versus multiple species in an assemblage?

and species proneness to deformities. These questions, we believe, are of interest when using diatom teratologies as biomarkers of stress. This topic is especially of concern because diatom teratologies are increasingly used in biomonitoring as shown by the rising number of publications on diatom malformations (Fig. 2). With this paper, we aim to initiate a discussion on the subject. Hopefully, this discussion will create new avenues for using teratologies as biomarkers of stress and contamination. The ultimate goal would be the creation of an index including additional biological descriptors to complement the teratology-based metric.

\section{Teratology formation and transmission}

\subsection{Valve formation}

Current routine identifications of diatom species are based on morphological characters such as symmetry, shape, stria density, and ornamentation. The characteristic shape of each diatom species results from a combination of genetic and cellular based processes that are regulated by environmental factors. There is a wealth of literature on valve morphogenesis, based both on ultrastructure observations and cellular (molecular and biochemical) processes. Descriptions of the processes involved in valve formation are provided, among others, by 


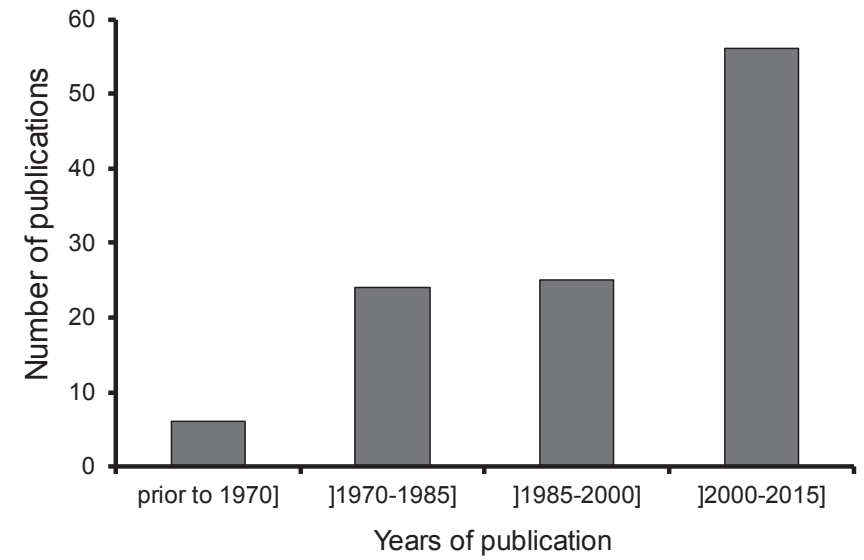

Fig. 2. Number of papers on the topic of diatom teratologies in freshwater environments (natural and laboratory conditions) published from 1890 to 2015. Database provided in Supplementary Material.

the following authors: Cox (2012), Cox et al. (2012), Falasco et al. (2009a), Gordon et al. (2009), Knight et al. (2016), Kröger et al., 1994, Pickett-Heaps et al. (1979), Round et al. (1990), Sato et al. (2011) and Schmid and Schulz (1979). Although a detailed description of cellular processes involved in valve formation is far beyond the scope of this discussion, the following section briefly summarizes the information given in the above-mentioned publications.

Diatoms have external cell walls (frustule) composed of two valves made of amorphous polymerized silica. They mainly reproduce asexually during the life cycle with short periods of sexual activity. During cell division (mitosis), a new hypotheca (internal valve) is formed after cytokinesis. Silica polymerization occurs in a membrane-bound vesicle (silica deposition vesicle; SDV) within the protoplast (Knight et al., 2016). In pennate species, a microtubule center is associated with initiation of the SDV (Pickett-Heaps et al., 1979, 1990). The sternum (with or without a raphe) is the first structure to be formed followed by a perpendicular development of virgae (striae). In raphid diatoms the primary side of the sternum develops, then curves and fuses with the later-formed secondary side; the point of fusion generally appears as an irregular stria called the Voigt discontinuity or Voigt fault (Mann, 1981). Sketches and pictures of valve morphogenesis are presented in Cox (2012), Cox et al. (2012) and in Sato et al. (2011). The size of the new hypotheca formed by each daughter cell is constrained by the size of the parent valves, resulting in a gradual size reduction over time. Sexual reproduction initiates the formation of auxospores which can ultimately regenerate into large initial frustules (see Sato et al., 2008 for information on auxosporulation). Asexual spore formation (Drebes 1966; Gallagher 1983) may also lead to large initial frustules and a larger population. Auxospore initial cells may differ greatly in morphology compared to cells forming during the division and these differences should not be confused with deformity. These initial cells are however rather rare.

\subsection{Overview of teratogenesis}

Deformities are commonly observed in natural diatom assemblages, but their frequency of occurrence is generally low $(<0.5 \%$ according to Arini et al., 2012 and Morin et al., 2008a). The presence of multiple stressors, however, can significantly increase the proportions of deformed individuals. Falasco et al. (2009a) reviewed different types of deformities observed on diatom valves and the various potential mechanisms involved, as well as numerous environmental factors known to be responsible for such aberrations. We are aware that various stresses may induce teratologies, but here we focus our observations and discussion on the effects of toxic contaminants such as metals and organic compounds.

Based on the current literature, mechanisms inducing teratologies are not fully understood. Due to physical (e.g., crowding, grazing) or chemical stresses (e.g., metals, pesticides, nutrient depletion), cellular processes involved in cell division and valve formation may be altered (Barber and Carter, 1981; Cox, 1890). One reliable explanation for teratology formation involves the microtubular system, an active part in the movement of silica towards the SDV. Exposure to anti-microtubule drugs (Schmid, 1980) or a pesticide (Debenest et al., 2008), can affect the diatom microtubular system (including microfilaments), leading to abnormal nucleus formation during cell division and to the deformation of the new valve. Licursi and Gomez (2013) observed a significant increase in the production of abnormal nuclei (dislocation and membrane breakage) in mature biofilms exposed to hexavalent chromium. No teratological forms were observed, but the biofilm was exposed to the contaminant only for a short duration ( $96 \mathrm{~h}$ ).

Malformations can also be induced by other independent factors. For instance, malfunctions of proteins involved in silica transport and deposition (Knight et al., 2016; Kröger et al., 1994, 1996, 1997; Kröger and Poulsen, 2008), or proteins responsible for maintenance, structural and mechanical integrity of the valve (Kröger and Poulsen, 2008; Santos et al., 2013) would have significant impacts on teratologies. Metals could also inhibit silica uptake due to metal ion binding on the cell membrane (Falasco et al., 2009a). Likewise, the initial formation of the valve can be affected by a lack of transverse perizonial bands on the initial cell (Chepurnov et al., 2004; Mann, 1982, 1986; Sabbe et al., 2004; Sato et al., 2008; Toyoda et al., 2005; von Stosch, 1982; Williams 2001). Finally, biologically-induced damage related to bottom-up and top-down processes (e.g., parasitism, grazing, crowding) represent natural stresses that may result in abnormal valves (Barber and Carter, 1981; Huber-Pestalozzi, 1946; Stoermer and Andresen, 2006).

Deformities can also be the consequence of plastid abnormalities or mis-positioning during cell division, as observed in standard laboratory cultures of Asterionella formosa Hassall (Kojadinovic-Sirinelli, Bioénérgétique et Ingénierie des Protéines Laboratory UMR7281 AMUCNRS, France; unpublished results) and under metal exposure in Tabellaria flocculosa (Roth) Kütz. (Kahlert, Swedish University of Agricultural Sciences; unpublished results). When considering normal cellular morphotypes of $A$. formosa, plastids are symmetrically positioned within dividing cell (Fig. 3A). In some cases, the plastids are significantly larger than normal, which may be the consequence of a microtubular system defect. This seems to induce formation of curved epivalve walls (Fig. 3B). As a consequence, daughter cells appear
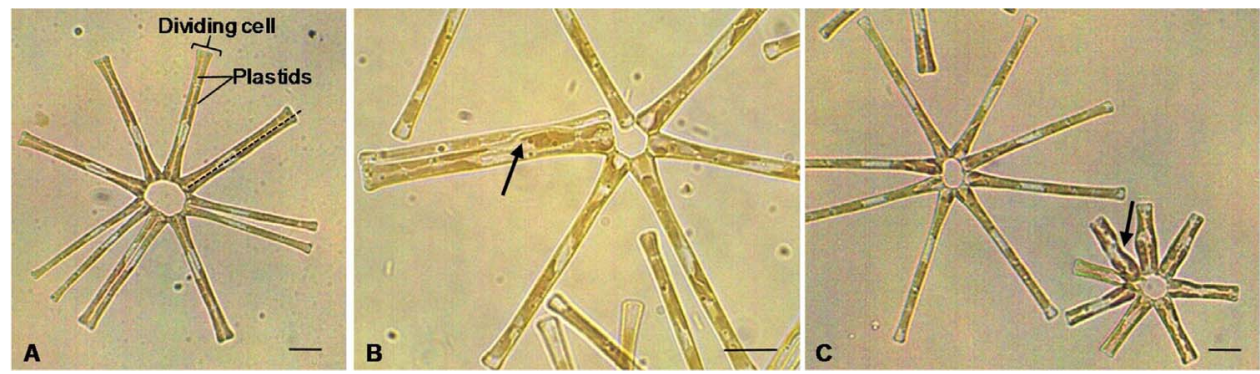

Fig. 3. Light micrographs of Asterionella formosa grown in laboratory conditions. Micrographs were made on a culture in late exponential growth phase. A: Normal cellular morphotype of an A. formosa colony. The dashed line represents septum position in a dividing cell. B: Abnormal morphotype. The arrow points to a curved epivalve wall. C: Colony of normally-sized cells (about $50 \mu \mathrm{m}$ long) cohabiting with a colony of small and deformed cells (about $15-20 \mu \mathrm{m}$ long). Scale bars represent $10 \mu \mathrm{m}$. 
deformed (Fig. 3C). Extreme curvatures of the valve results in the formation of much smaller daughter cells (15-20 $\mu \mathrm{m}$; Fig. 3C) compared to the mother cells (about $40-50 \mu \mathrm{m}$ ). The "small-cell" characteristic is then transmitted to subsequent daughter cells, resulting in colonies of small individuals. In this case, the deformity and reduction in size does not seem to decrease cell fitness, because the small-sized cells reproduce as efficiently as the normally-sized cells, or even faster. In this case, the abrupt size reduction is certainly a response to the environment. Interestingly, abnormally small cells seem to appear at the end of the exponential growth phase and to increase in frequency as cultures age (Falasco et al., 2009b). This may suggest that the "small-size aberration" was a consequence of nutrient depletion or the production of secondary metabolites that could stress A. formosa. Sato et al. (2008) also reported a sharp decrease in cell size accompanied by deformed individuals bearing two valves of unequal size in old cultures.

According to Hustedt (1956) and Granetti (1968), certain morphological alterations are not induced by genetic changes, because the diatoms return to their typical form during the subsequent sexual cycle. In contrast, other authors have elevated altered forms to the variety or species level (e.g., Jüttner et al., 2013), thus assuming taxonomic distinctness. Biochemical and molecular investigations of clones with distinct morphotypes would thus be required to assess whether deformities are short term phenotypic responses, problems with gene expression (i.e., assembly line malfunction) or true alterations in the genes. The evolution of a species, at least in part, is a temporal process of physiological (teratological) changes resulting in "deviations from the normal type of organism/species". The gain or loss of any structure, like for example rimoportulae, potentially represents a new species. Even a change in the position of a structure can constitute a new species. Teratologies under temporal changes can influence populations or species. For the purpose of this discussion paper, longer temporal events of teratology (reproduction of a selected deformity over generations) can lead to speciation events, while short term teratologies (not reproductively viable in the next generation after sexual reproduction) are considered dead end and non-taxonomically significant.

\subsection{Abnormal overall shape}

The initial question here would be: "when does an atypical valve outline fall into the abnormal category?" For the purpose of this discussion, an abnormal outline is when aberrations affect valve symmetry, or when defects alter the "normal" shape of the diatom. This working definition excludes deviations from expected shape changes as cells get smaller (natural variability). Variability in shape related to post auxosporulation is difficult to differentiate from an abnormal form, but these forms are considered as rare. The second question is when does the deviation from the "common shape" become significant enough to be deformed? This question is particularly relevant when aberrations are subtle and subjectively identified with variability between analysts. On the other hand, marked deviations from the normal shape are easy to notice and classify as aberrant. Deformities affecting the general valve outline are assumed to be passed along from generation to generation through asexual cell division. Replication of the deformity happens because the newly formed valves must "fit into" the older valves; thus, the aberration is copied and the number of abnormal valves increases even though "new errors" do not occur. This scenario is clearly stated in numerous publications, as for instance:

"A morphological variation in the frustules outline is easily transmitted through generations, others, like the pattern and distribution of the striae, are not: this is the reason for the lower frequency of the latter alterations." Falasco et al. (2009a)

"If the damaged cells survive, they will be able to reproduce: in this case, the daughter clones will build their hypotheca on the basis of the damaged epitheca, spreading the abnormal shape through the generations" Stoermer and Andresen (2006)
This propagation of abnormal valves during cell division may explain why valve outline deformities are the most frequently reported in the literature and with the highest abundances. For example, Leguay et al. (2016) observed high abundances of individuals presenting abnormal valve outlines in two small effluents draining abandoned mine tailings (50\% and 16\%, all observed on the same Eunotia species). Valve outline deformities reaching $20-25 \%$ (on Fragilaria pectinalis (O.F.Müll.) Lyngb.) were observed at a site located downstream of textile industries introducing glyphosate in the Cleurie River, Vosges, France (Heudre, DREAL Grand Est, Strasbourg, France; unpublished results). Kahlert (2012) found deformities of up to $22 \%$ on Eunotia species in a $\mathrm{Pb}$ contaminated site. The effect of carry-over from cell division could explain the high frequency of abnormal individuals (reaching up to $>90 \%$ with a marked indentation) in a culture of Gomphonema gracile Ehrenb. from the IRSTEA-Bordeaux collection in France (Morin, IRSTEA-Bordeaux, France; unpublished results).

If cell division is the key agent for the transmission of valves with abnormal outlines due to the "copying effect", then how does the first frustule get deformed? An initial abnormal valve must start the cascade of teratologies: logically, we could argue that the initial deformity appears during sexual reproduction when the frustule of a new cell is formed without the presence of an epivalve as a template. Hustedt (1956) discussed this scenario where he suggested that particular environmental conditions during auxospore formation may induce morphological changes that are perpetuated during vegetative reproduction, giving rise to a population with a morphology different from the parental line. This new abnormal cell would then divide by mitosis and legate the abnormal shape to all subsequent daughter cells, as also suggested by Stoermer (1967). This is in-line with the observation that the above-mentioned $G$. gracile bearing the marked incision on the margin is ca. $50 \%$ larger than its "normal" congeners of the same age. On the other hand, there is also the possibility or hypothesis in the gradual appearance of an abnormal outline that is accentuated from generation to generation. First, a very subtle deviation from the normal pattern appears on the forming hypovalve and a deformity is not noticed. This subtle deviation from the normal shape is progressively accentuated by the newly forming hypovalve leading to a very mild abnormality of the overall shape, and so on through multiple successive divisions resulting in a population of slightly abnormal to markedly deformed individuals. If this scenario is possible, then the opposite situation could also be plausible: the subtle deviation from the normal overall shape is "fixed" or "repaired" during subsequent cell divisions instead of being accentuated. In another scenario, the epivalve could be normal and the hypovalve markedly deformed, potentially resulting in an individual that would not be viable. Sato et al. (2008) reported something similar in old cultures of Grammatophora marina (Lyngb.) Kütz. where drastic differences in valve length between epivalve and hypovalve (up to $50 \%$ relative to epitheca) were observed, suggesting that a "perfect fit" is not always necessary. These authors also observed cells that had larger hypothecae than epithecae, implying expansion before or during cell division. In this case, are these growth forms viable and sustainable?

\subsection{Other deformities}

Although irregular valve outlines appear to be a common and frequent type of teratology, it is not always the dominant type of deformity observed within a given population. For instance, Arini et al. (2013) found abnormal striation patterns and mixed deformities to be the most frequently observed aberration in a Cd exposure experiment using a culture of Planothidium frequentissimum Lange-Bertalot. Deformities on the same species were observed more frequently on the rapheless-valve and the structure affected was generally the cavum and less frequently the striae (Falasco, Aquatic Ecosystem Lab., DBIOS, Italy; unpublished results from field samples). 
The sternum is the first structure produced by the SDV; if an aberration occurs in this region, other/additional aberrations may subsequently appear in striation patterns occurring later during valve formation. This could therefore be considered as "collateral damage" because of an abnormal sternum (including the raphe), leading to mixed deformities. For example, Estes and Dute (1994) have shown that raphe aberrations can lead to subsequent valve and virgae (striae) distortions. However, abnormal striation patterns have also been observed on valves showing a normal raphe or sternum system. Because the appearance of striae aberrations is believed to happen later during valve formation, should these teratologies be considered as a signal reflecting a mild deleterious effect? The same reasoning applies to the general valve outline; should it be considered as a minor response to stress or as collateral damage? Another interesting deformity is the presence of multiple rimoportulae on Diatoma vulgaris valves. Rimoportulae are formed later in the morphogenesis process; should this type of alteration be considered equal to raphe or striae abnormalities? Our observations on raphid diatoms suggest that individuals generally exhibit abnormal striation or sternum/raphe anomalies only in one valve, while the other valve is normal (Fig. 4). The possibility of an abnormal structure on the two valves of a cell is not excluded, and would therefore suggest two independent responses to stress. A mother cell with one abnormal valve (e.g., raphe aberration) will produce one normal daughter cell and one abnormal daughter cell, resulting in a decreasing proportion of teratologies if no additional "errors" occur. This makes deformities in diatom valve structure, other than the abnormal outline category, good biomarkers of stress because the deformity is not directly transmitted and multiplied though cell division. In other words, aberrations occurring at different stages of valve formation may not all have the same significance/severity or ecological signal, and this may represent important information to include in bioassessments. The problem, however, is that these abnormalities are often rare.

\subsection{Are deformed diatoms viable, fit and able to reproduce?}

Based on numerous laboratory observations made by authors of this publication, it seems clear that deformed diatoms in cultures are able to reproduce, even sometimes better than the normal forms (e.g., deformed Asterionella formosa Hassall, Section 2.2 and deformed Gomphonema gracile, section 2.3). However, the ability of abnormal cells to survive and compete in natural environments is potentially affected. Teratologies have different impacts on physiological and ecological sustainability depending on the particular valve structure that was altered. Valve outline deformation, for instance, could prevent the correct linking spine connections during colony formation. Alterations in the raphe system could limit the locomotion of motile diatoms (although this has not been observed in preliminary experiments conducted on $G$. gracile, Morin, IRSTEA-Bordeaux, France; unpublished results). Motility represents an important ecological trait especially in unstable environmental conditions because species can move to find refuge in more suitable habitats. Alterations in the areolae patterns located within the apical pore fields may prevent the correct adhesion of erected or pedunculated taxa to the substrate, impairing their ability to reach the top layer of the biofilm and compete for light and nutrients.

\section{The ecological meaning of teratological forms}

\subsection{Types of deformities}

A good fit was observed in certain studies between the abundance of teratologies and the presence of a contaminant (review in Morin et al., 2012). However, other studies have failed to show a clear relationship between the frequency of abnormal forms and the level of contamination along a gradient (e.g., Fernández et al., 2017; Lavoie et al., 2012; Leguay et al., 2015); this is the "raison d'être" of this paper. Here we discuss potential avenues to deepen our interpretation of the ecological signal provided by diatoms. Do deformed cells reproduce normally? Do they consistently reproduce the teratology? These questions are intimately linked to the various types of teratologies observed. The type of deformity may therefore be an important factor to consider in biomonitoring because they may not all provide equivalent information (Fig. 5). Most authors agree to categorize teratological forms based on their type, summarized as follow: (i) irregular valve outline/abnormal shape, (ii) atypical sternum/raphe, (iii) aberrant stria/areolae pattern, (iv) mixed deformities. Despite the fact that various types of aberrations are reported, most authors pool them together as an overall percentage of teratologies (e.g., Lavoie et al., 2012; Leguay et al., 2015; , 2008a; , 2012; Roubeix et al., 2011) and relate this stress indicator to contamination. Only a few studies report the proportion of each type of deformity (e.g., Arini et al., 2013; Pandey et al., 2014, 2015; Pandey and Bergey, 2016).

Based on a literature review of more than 100 publications on diatoms and teratologies, we created an inventory of $>600$ entries concerning various diatom taxa reported as deformed (and the type of teratology observed) as a response to diverse stresses (Appendix A). This database is an updated version of the work presented in Falasco et al. (2009a). We assigned each of the reported teratologies to one of the four types of aberrations, which resulted in a clear dominance of abnormalities affecting valve outlines (Fig. 6).

Fig. 4. Examples of diatom frustules showing deformities on one valve, while the other valve is normal. The first three examples represent striae aberrations, while the last two pictures show mixed deformities with raphe and striae aberrations (see section 3.1. Types of deformities). Scale bar $=10 \mu \mathrm{m}$.
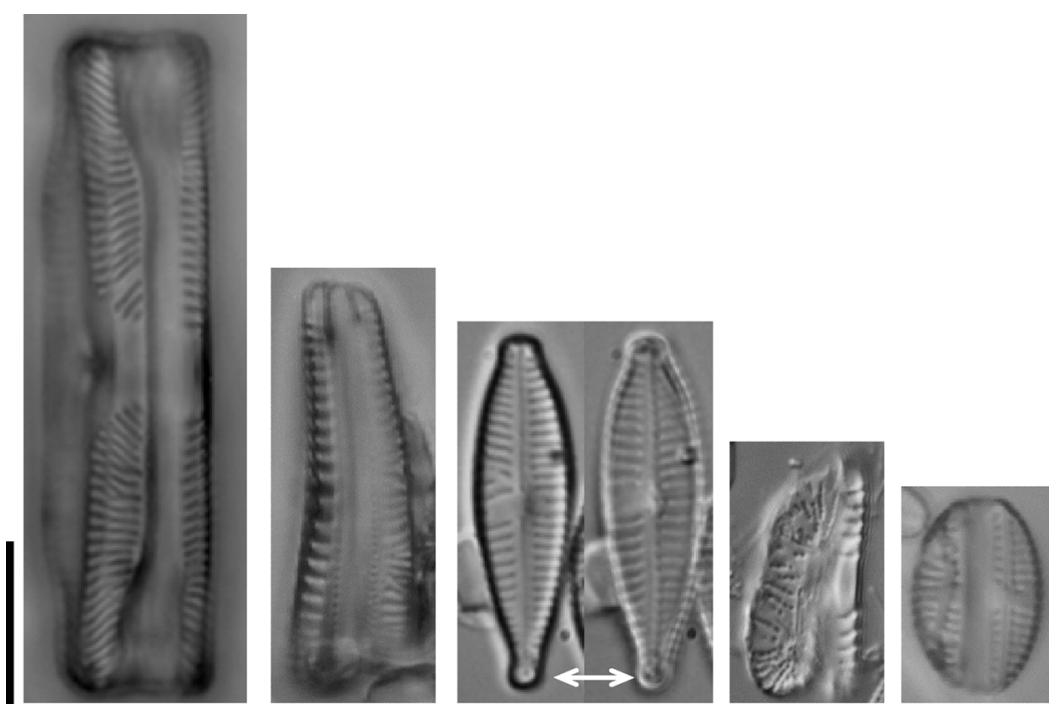


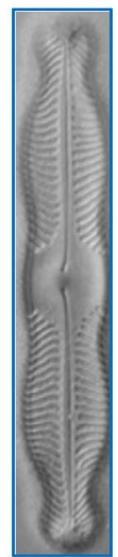

normal

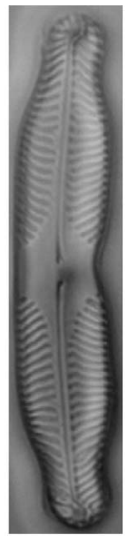

(i)

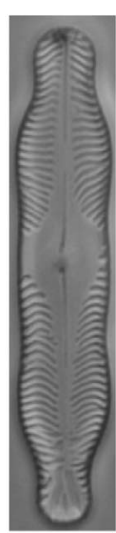

(ii)

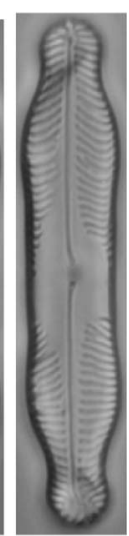

(iii)

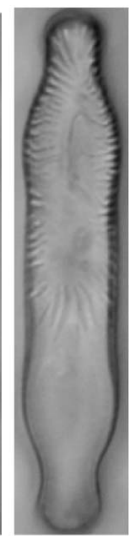

(iv)

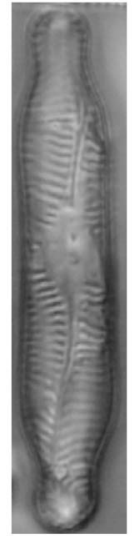

(iv)

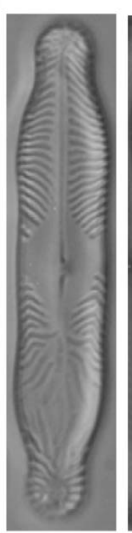

(iv)

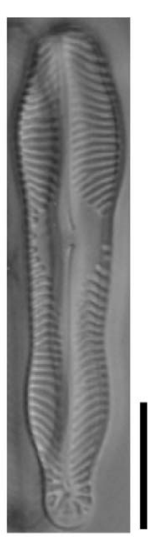

(iv)
Fig. 5. Examples of different types (i, ii, iii and iv) and degrees of deformities observed on Pinnularia sp. valves in a culture exposed to cadmium. (i) irregular valve outline/abnormal shape, (ii) atypical sternum/raphe (iii) aberrant striae/areolae pattern, (iv) mixed deformities. Should they all be considered equally meaningful for biomonitoring purposes? Scale bar $=10 \mu \mathrm{m}$.

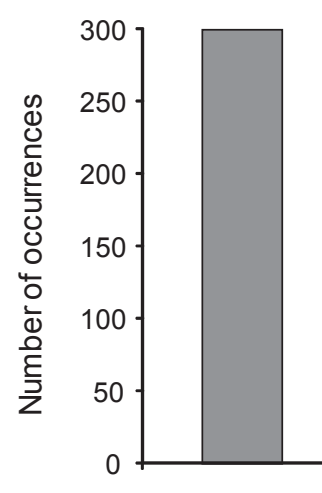

i) outline ii) sternum/raphe iii) striation

Types of teratologies

\subsection{Are deformities toxicant-specific?}

As deformities are expected to occur during morphogenesis, different types of deformities may result from exposure to contaminants with different toxic modes of actions. Are all toxicants likely to induce similar deformities? From our database, the occurrences of the different types of deformities were grouped into three categories of hypothesized cause (including single source and mixtures): metal(s), organic compound(s), and a third one with all other suspected causes (a priori nontoxic) such as crowding, parasitism, and excess nutrients (excluding unspecified causes). The results presented in Fig. 7 should be interpreted with caution with unequal data available for the different categories (in particular, low number of data for organic compounds). Similar patterns in the distribution of deformities were found with exposure to organic and inorganic toxicants; in more than $50 \%$ of the cases, solely the valve outline was mentioned as being affected. Other types of deformities were, by decreasing order of frequency: striation (ca. 20\%), followed by mixed deformities (ca. 14\%), and sternum/ raphe alterations (ca. 12\%). This is in concordance with other observations indicating that exposures to metals led to about the same degree of deformations as exposures to herbicides; in both cases, the highest toxin concentrations caused the highest ratio of sternum/raphe deformities to outline deformities (Kahlert, 2012). In contrast, other stresses than toxic exposure conditions (or unknown) resulted in deformities affecting cell outline in $45 \%$ of the cases, while $30 \%$ were mixed teratologies, $20 \%$ affected the striae and less than $10 \%$ the sternum/raphe system. Thus, the distributions of deformity types for toxic and non-toxic exposure were slightly different, which underscores the potential of deformity type to clarify the nature of environmental pressures and strengthens the need for describing precisely the
Fig. 6. Types of deformities reported in the literature for various diatom species. The data used to create this graph come from the publications reported in Appendix A.

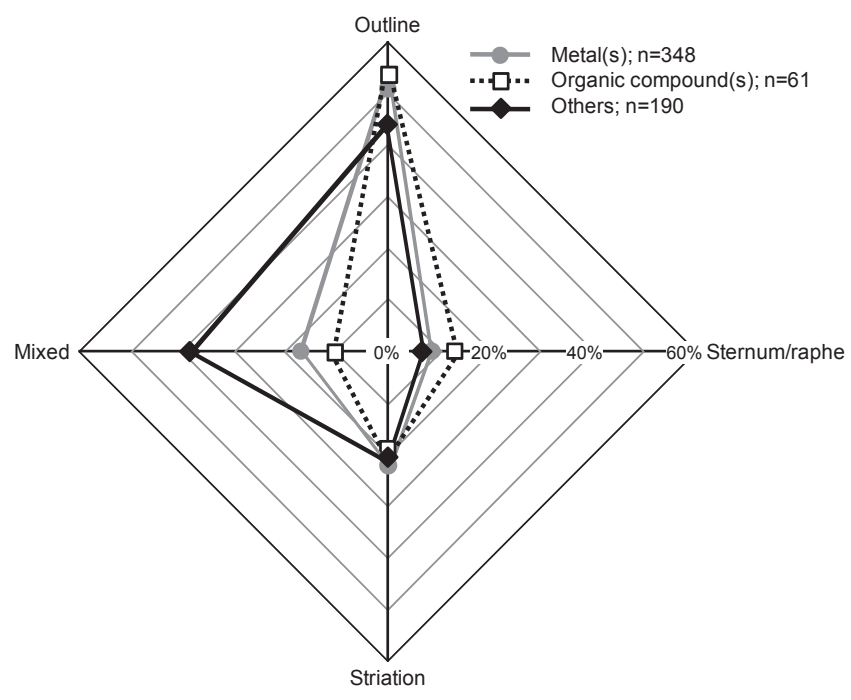

Fig. 7. Deformity occurrence (expressed as \%) classified by types and reported causes of stress in field and laboratory studies. The data were gathered from the information available in the publications presented in Appendix A. Data were not considered for this graph when the cause of teratology was not specified.

deformities observed.

Fig. 7 suggests that mixed deformities occur more frequently for environmental stresses (including various perturbations such as nutrient depletion) than for contaminant-related stresses. However, timing could also be a potential cause of differentiation between the various types of aberrations. Timing here can be interpreted in two very 
different ways. First, it can be related to the chronology of teratology appearance in ecosystems or cultures. For example, if an abnormal valve outline aberration occurs early during an experiment, then this deformity will be transmitted and multiplied through cell division. However, if the individual bearing the abnormal valve shape appears later in time (or if this type of deformity does not occur), then other types of deformities may appear and become dominant. On the other hand, the presence of one type of deformity over another could also be associated with the moment during cell formation at which the stress occurs, i.e., that the contaminant reached the inner cell during the formation of one structure or another. There is also the possibility that an abnormal outline deformity is a secondary result from an impact affecting another mechanism of valve formation.

\subsection{Proneness to deformities and tolerance to contamination}

Are all diatom species equally prone to different types of deformities? From the literature published over the past ca. 70 years, we present species observed, the type of deformities noted and the tolerance to contamination when reported (Appendix A). Based on these data, we observed that the most common aberration is valve shape (as also presented in Fig. 6) and that this aberration is particularly evident for araphid species. Deformities in araphid species had ca. $60 \%$ of the reported deformities as irregular shape. This finding suggests that araphid diatoms may be more "prone" to showing abnormal valve outlines compared to raphid or centric diatoms. Therefore, araphid diatoms may not be good biomarkers compared to other species especially considering that shape aberration is multiplied by cell division (see above discussion). However, proneness to different types of deformities differed among long and narrow araphids: Fragilaria species mostly exhibited outline deformity (67\%), compared to the robust valves of Ulnaria species (29\%).

In addition to araphids, Eunotia species also tend to show abnormal shapes ( $>75 \%$ in our database). This suggests that the formation of a long and narrow valve may provide more possibility for errors to occur or that the araphid proneness to deform may result from the absence of a well-developed primary and secondary sternum/raphe structure that could strengthen the valve. This argument may also be valid for Eunotia species that have short raphes at the apices, which is supported by irregularities mostly observed in the middle portion of the valve. Specimens of the Cocconeis placentula Ehrenb. complex (monoraphids) from natural assemblages collected in contaminated and uncontaminated waters have also frequently been observed with irregular valve outlines in Italian streams (Falasco, Aquatic Ecosystem Lab., DBIOS, Italy; unpublished results). This genus might be considered as unreliable in the detection of contamination because it seems to be prone to teratologies (mainly affecting valve outline which is transmitted during cell division).

A puzzling observation is the presence of deformities affecting only one species among the array of other species composing the assemblage. The abnormal specimens may all belong to the dominant species in the assemblage or not. When this situation is encountered for irregular shape teratologies, we can argue that this is in part due to the transmission of the aberration during cell division. This was the case at a mine site (with an assemblage almost entirely composed of two species) where $16 \%$ of the valves showed an abnormal outline and were all observed on species of Eunotia, while no teratology was observed on the other dominant species (Leguay et al., 2015). The same situation was noted in the previously mentioned example from the French River contaminated by a pesticide where $20-25 \%$ of abnormal shapes were observed on $F$. pectinalis (O.F. Müll.) Gray. On the other hand, when only one species in the assemblage presents deformities of the sternum/raphe structure and/or the striae, this suggests a true response to a stress event by a species prone to deformities. This has been observed at a mine site (high $\mathrm{Cu}$ ) where deformities reached $8 \%$ and were always observed on Achnanthidium deflexum (Reimer) Kingston (Leguay et al., 2015).

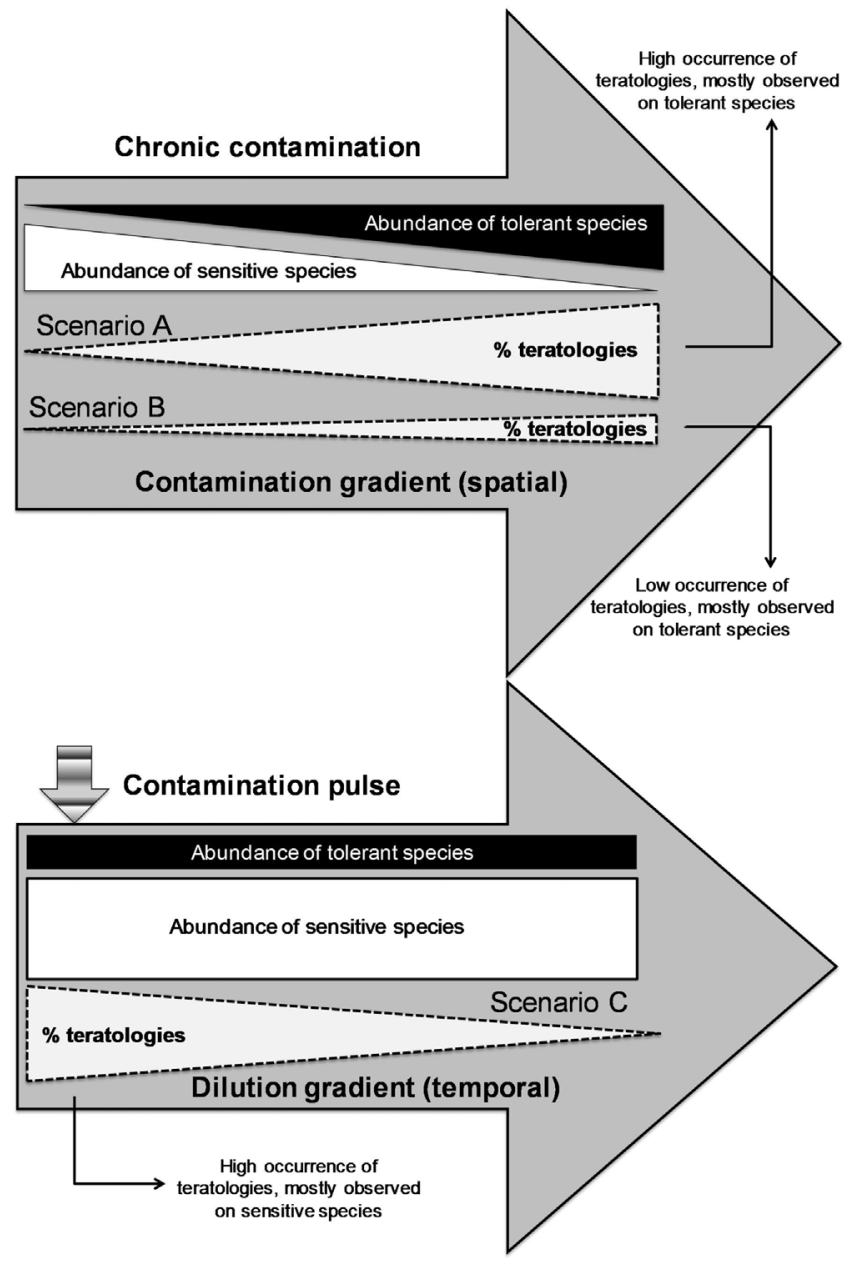

Fig. 8. Conceptual model for the occurrence of teratologies from contaminant exposure among tolerant and sensitive species. In scenario $\mathrm{A}$, the assemblage is prone to deformities and their occurrence increases with contaminant concentration. In scenario B, the occurrence of deformities is low due to the predominance of cells that typically do not exhibit structural changes in the presence of contaminants. Since sensitive species are likely to be eliminated from the assemblage as contamination increases, the occurrence of valve deformities observed on sensitive species in this assemblage for scenarios A and B is low. Finally, in scenario C, short term or pulse exposures are not likely to alter the assemblage composition and the occurrence of deformities is likely to affect mostly sensitive species as tolerant species are rare.

Numerous species are known to be tolerant to contaminants. For example, Morin et al. (2012) provide a list of diatom species that are cited in the literature as tolerant or intolerant to metals. As explained in their review, species that are able to tolerate toxic stress will thrive and dominate over sensitive species. Similar observations led to a concept called Pollution-Induced Community Tolerance (PICT) developed by Blanck et al. (1988). According to this paradigm, the structure of a stressed assemblage is rearranged in a manner that increases the overall assemblage tolerance to the toxicant. Considering an assemblage where most species are tolerant, we would expect to observe less teratologies. However, this is not necessarily the case as aberrations are commonly encountered on tolerant species. This observation is not a surprise because even tolerant and dominant species are still under stress conditions (Fig. 8, scenario A). In this scenario, most teratologies are observed on tolerant species and very few on sensitive species due to their rarity in the assemblage. However, this is not always the case as some tolerant species are less prone to deformities than others (Fig. 8, scenario B), resulting in fewer deformed valves in highly contaminated environments. This raises the question as to whether deformities should be weighted as a function of species proneness to abnormalities. Furthermore, species have been shown to develop tolerance resulting in a 

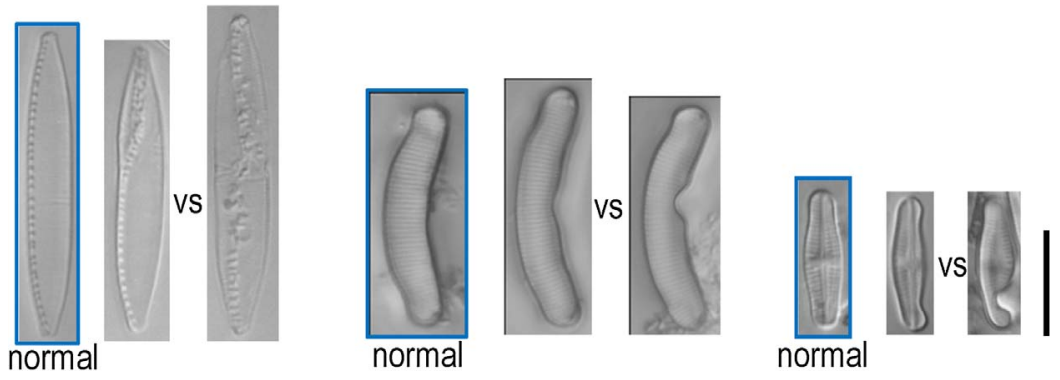

Fig. 9. Normal valve, slightly deformed valve, and markedly deformed valve of Nitzschia palea, Eunotia sp., and Achnanthidium minutissimum exposed to metals. Scale bar $=10 \mu \mathrm{m}$. population adapted to certain stressors, which then may or may not show deformities. For example, Roubeix et al. (2012) observed that the same species isolated from upstream and downstream of a Cu-contaminated site has different sensitivities to $\mathrm{Cu}$, i.e., that not all populations of a species have the same tolerance. We should therefore expect variability in the sensitivity to deformation, even within tolerant species.

There is also the scenario where diatom assemblages are stressed by intermittent events of contamination; a spill from a mine tailing pond for example. If such assemblages are dominated by metal-sensitive species, we would expect to observe more teratologies on these species and very few on tolerant species as they are rare (Fig. 8, scenario C). This, of course, is based on the hypothesis that deformities will appear on sensitive species faster than the time it takes the assemblages to restructure towards a dominance of tolerant species (which would bring us back to the above-mentioned scenarios; also see Section 5.3).

We would furthermore expect that tolerance to deformities would not only be species-dependent, but also environment-dependent. In general, we hypothezise that suboptimal conditions (e.g., $\mathrm{pH}$, nutrients, light, competition) favour the occurrence of teratological forms, while optimal conditions decrease their occurrence. Environmental conditions would then set the baseline on how sensitive a diatom assemblage is to toxic impacts. For example, some samples from pristine forest wetlands/swamps with low $\mathrm{pH}$ and no source of contaminants in the Republic of the Congo showed cell outline deformities (2\%) (Taylor, Unit for Environmental Sciences and Management, NWU, South Africa; unpublished results). The presence of teratologies was therefore assumed to be attributed to the low $\mathrm{pH}$ of the environment or to the fact that these isolated systems had become nutrient limited. The key message from this section is to acknowledge that deformities may be found under different stresses (not only contamination by metals or organic compounds), and also that deformed diatoms are not always observed in highly contaminated environments.

\section{Issues with teratology assessment}

\subsection{Small species and problematic side views}

Certain abnormalities are more or less invisible under a light microscope, particularly for small species. There are numerous publications reporting valve aberrations observed with a scanning electron microscope which would otherwise be missed with a regular microscope (e.g., Morin et al., 2008c). This is problematic in a biomonitoring context, especially when a contaminated site is dominated by small species such as Fistulifera saprophila (Lange-Bertalot \& Bonk) LangeBertalot, Mayamaea atomus (Kütz.) Lange-Bertalot or Achnanthidium minutissimum Kütz., or by densely striated species like Nitzschia palea (Kütz.) W.Sm. In these cases, the frequency of deformities may be underestimated. Would it be more appropriate to calculate a percentage of teratologies considering only the species for which all structures are easily seen under a light microscope? In the same line of thought, how should we deal with specimens observed in girdle view where deformities are often impossible to see? This situation is of concern when the dominant species tend to settle on their side, such as species belonging to the genera Achnanthidium, Gomphonema, and Eunotia. It could therefore be more appropriate for bioassessment purposes to calculate the teratology percentages based on valve view specimens only. This recognizes that the proportion of aberrations on certain species, often seen in girdle view, may consequently be underestimated. A separate count of deformities for species regularly observed side-ways could also be performed only considering valve-view specimens, and the percentage of teratologies could then be extrapolated to the total valves enumerated for this species. This proposal of a separate count is based on the likely hypothesis that a deformed diatom has the same probability to lay in one or the other view as normal specimens.

\subsection{How to score the severity of the teratology?}

The severity of teratologies, i.e. the degree of deviation from the "normal" valve, is usually not assessed in biomonitoring (Fig. 9). Would this information be useful to better interpret the magnitude of the stress? This question leads to another: how to quantify the severity of valve deformities depending on the type of abnormality? The line between a normal variation and a slight aberration is already difficult to draw (Cantonati et al., 2014); is it possible to go further in this teratology assessment and score the deformities under slight-mediumpronounced deviations from the normal shape/pattern? This additional information could be of ecological interest, but might also be very subjective and limited to individual studies or situations. Image analysis might help to solve this problem in the future, although preliminary tests using valve shape have been inconclusive so far (Falasco, 2009).

\section{Implications for biomonitoring}

\subsection{Deformities as an indicator of unhealthy conditions}

The frequency of deformities has been reported as a good biomarker of metal contamination, and in fewer studies to organic contamination. In most cases the effects of contamination on diatom teratologies were evaluated using percent of deformities regardless of their type. The majority of the studies either compared a contaminated site with a reference site or tested experimental conditions with a control and one or two contamination levels. As examples, Duong et al. (2008) and Morin et al. (2008a) found a significantly higher presence of teratologies in a stream contaminated by metals ( $\mathrm{Cd}$ and $\mathrm{Zn}$ ) compared to its upstream control. In laboratory experiments using a monospecific diatom culture or on biofilm communities exposed to three levels of $\mathrm{Cd}$ (control, 10-20 $\mu \mathrm{g} / \mathrm{l}$ and $100 \mu \mathrm{g} / \mathrm{l}$ ), Arini et al. (2013), Gold et al. (2003) and Morin et al. (2008b) observed significantly higher proportions of deformed individuals in the contaminated conditions, but the overall difference in \% teratologies between concentrations of Cd was not statistically significant. These examples underscore the usefulness of teratologies as a biomarker of stress. However, linking the magnitude of the response to the level of contamination is not as straightforward as comparing contaminated and reference conditions. For example, Cattaneo et al. (2004) only found a weak relationship between deformities and metal concentrations in lake sediments. Fernández et al. (2017) and Lavoie et al. (2012) were not able to correlate the 
occurrence of valve deformities with a gradient in metal concentrations in a contaminated stream. Leguay et al. (2015) observed the highest proportions of deformities at the most contaminated sites, but significant correlations were not observed using each metal separately and the confounding effects of metal contamination and low $\mathrm{pH}(\sim 3)$ made the direct cause-effect link difficult to assess. In these last studies, more aberrant diatom valves were observed at the contaminated sites compared to the reference sites, but the correlation between teratologies and metal concentrations collapsed in the middle portion of the contamination gradient. In laboratory cultures, a linear correlation has been observed between the frequency of deformities and metal concentrations, except for the highest concentration in the gradient where fewer deformations were noted (Gonçalves, University of Aveiro, Portugual and Swedish University of Agricultural Sciences, Uppsala, Sweden; unpublished results). This result could be explained by the fact that deformed cells may be less viable at very high metal concentrations.

Using an estimate of metal exposure/toxicity (e.g. CCU, cumulative criterion unit score; Clements et al., 2000) may result in a better fit between metal contamination (expressed as categories of CCU) and deformity frequency. Using this approach, Morin et al. (2012) demonstrated that $>0.5 \%$ of deformities were found in "high metal" conditions. Falasco et al. (2009b) used a similar approach and also observed a significant positive correlation between metals in river sediments (Cd and $\mathrm{Zn}$ expressed as a toxicity coefficient) and deformities (expressed as deformity factors). Some metric of integrated information summarizing (i) the response of diatoms to contaminants (e.g. score based on teratologies) and (ii) the cumulative stresses (e.g. using an overall "stress value") seems to be an interesting approach to establishing a link between contamination level and biomarker response.

\subsection{Refining ecological signals by weighing teratologies}

Water quality assessment with respect to toxic events linked to diatom indices could potentially be refined by "weighting the deformities" as a function of deformation type. Moreover, this assessment could also be pushed further by considering the severity of the deformity, the proneness of the species to present abnormal forms and diversity of the species affected. Although abnormal cells are often classified by types, there seems to be no ecological information extracted from this approach. Here, we raise the discussion on how (or if!) we could improve biomonitoring by considering the specific teratologies and their severity by modifying their weight/importance. A systematic notation/description of the type and severity of deformation and species affected would be required. Thus, "ecological profiles" of teratologies could be determined, as a function of the species affected (as suggested in Fernández et al., 2017) and type of deformity. Indeed, improving our understanding about life cycle processes and the various types of deformations would greatly enhance the assignment of impact scores for biomonitoring, which is the essence of this paper.

The observation that valve aberrations are routinely found in extremely contaminated conditions led Coste et al. (2009) to include the occurrence and abundance of deformed individuals in the calculation of the biological diatom index BDI. In their approach, observed deformities were assigned the worst water quality profile, meaning that their presence tends to lower the final water quality score. This means that the severity and type of malformation, and the species involved were not considered; all teratologies were scored equally. However, based on the discussion presented in Section 4, this approach may be simplistic and valuable ecological information on the characteristics of the deformities lost. For example, in the case of araphid diatoms prone to deformation (even in good quality waters, i.e., Cremer and Wagner, 2004), the presence of teratologies may not always reflect the true degree of contamination. As a case example, Lavoie et al. (2012) observed $0.25-1 \%$ deformations at a site highly contaminated by metals and dominated by A. minutissimum, while the number of abnormal forms increased up to $4 \%$ downstream at less contaminated sites with species potentially more prone to deformation. More specifically, all aberrations affected valve outline and were mostly observed on Fragilaria capucina Desm. For this reason, it was impossible for the authors to correlate metal concentrations with teratologies. In this particular scenario, changing the weight of the deformations based on the type of deformity recorded and by considering the species (and their proneness to form abnormal valves) would potentially better reflect the environmental conditions.

An experiment on the effect of Cd on a Pinnularia sp. (Lavoie, INRSETE, Quebec, Canada; unpublished results) will serve as an example illustrating the potential interest in scoring teratology severity. In this experiment, a higher percentage of deformed valves were observed after 7 days of exposure to $\mathrm{Cd}$ compared to a control. The observed teratologies were almost exclusively mild aberrations of the striation pattern. The proportions of deformed valves increased even more after 21 days of exposure, with more severe teratologies of different types (sternum/raphe, striae). In this experiment, considering the types and severity of the deformities (mild vs severe) would better define the response to Cd between 7 days and 21 days of exposure, which would bring additional information on toxicity during longer exposure times. Developing the use of geometric morphometry approaches could also help to quantitatively assess the deviation to the normal symmetry/ ornamentation.

Also worth discussing is the presence of abnormally shaped valves in high abundances. If mitosis is the main precursor for the occurrence of abnormal valve shape, then it is legitimate to wonder if these aberrations really reflect a response to a stressor or if they are the result of an error "inherited" from the mother cell? If cell division multiplies the number of valves showing abnormal outlines, then this type of deformity should potentially be down-weighted or not considered for biomonitoring. However, to identify valves with irregular shapes as a result of contamination versus inherited irregularities is near impossible without running parallel control studies.

Finally, the score related to the frequency of deformities could also be weighted by species diversity estimates. For example, if species diversity in the community is very low (e.g. one species, or one strongly dominating species and some rare species) there is a potential bias in the assessment of the response to a stressor. The impact may be overestimated if the species is prone to deformity, and underestimated otherwise. Therefore, in addition to considering the proneness to deformity, teratology-based monitoring could also include a metric where the $\%$ deformity is combined with information on species diversity. This should improve ecological interpretations. However, low diversity and strong dominance of one species are also typical symptoms of certain stresses such as metal contamination (see section 5.3).

\subsection{Biological descriptors complementing a teratology-based metrics}

This paper has focused on the presence of diatom valve teratologies as an indicator of environmental stress, specifically for contaminants such as metals and pesticides; this excludes eutrophication and acidification for which diatom-based indices and metrics already exist (Lavoie et al., 2006, 2014 and references therein). The teratology metric is gaining in popularity as seen by the number of recent publications on the subject. However, other biological descriptors or biomarkers have been reported to reflect biological integrity in contaminated environments. Although it is generally impossible to examine all metrics due to limited resources and time, the most informative approach would undoubtedly be based on incorporating multiple indicators.

One very simple metric to use that does not require any taxonomic knowledge is diatom cell density. Lower diatom cell counts are expected as a result of altered algal growth under contaminated stress conditions. This has for example been reported in metal-contaminated environments (e.g., Duong et al., 2010; Gold et al., 2002; Pandey et al., 
2014). However, this metric alone does not consistently reflect the response of diatoms to perturbation because numerous other factors such as water discharge or grazing pressure have an influence on algal abundance and biomass. Another simple metric to calculate is diversity. For example, metal loading possibly contributed to lowering diatom diversity in the Animas River watershed, Colorado (Sgro et al., 2007). On the other hand, diversity is also driven by many other factors which do not always correlate with ecosystem's health (Blanco et al., 2012). This multilayer condition has been noticed at sites with different scenarios of contamination (abandoned mine tailings in Canada, or industrial discharge in France), where assemblages were composed of 100\% Achnanthidium minutissimum (Lainé et al., 2014; Lavoie et al., 2012 Lavoie et al., 2012). In these cases, low diversity was not exclusively linked to metal contamination but also to low nutrients. Species diversity increased downstream in both systems which matched with dilution of the contamination; however, this could also be attributed to cell immigration and to increased nutrient concentrations downstream.

Assemblage structure also provides valuable information on ecosystems health as a shift from sensitive to tolerant species reflects a response to environmental characteristics. This assemblage-level response is believed to operate on a longer temporal scale as compared to the appearance of teratologies. This has been observed, for example, in a study with chronic metal exposure where deformed individuals were outcompeted and replaced by contamination-tolerant species, thus abnormal valves slowly disappeared from the assemblage (Morin et al., 2014). This suggests that the presence of deformities may be an early warning of short/spot events of high contamination, while the presence of tolerant species may reflect chronic exposure. The apparent temporal disparity could in part explain unclear response patterns observed under natural conditions when documenting teratologies alone as a biological descriptor.

Diatom frustule size is considered an indicator of environmental conditions, and selection towards small-sized individual and or species has been observed under contamination/stress conditions (Barral-Fraga et al., 2016; Ivorra et al., 1999; Luís et al., 2011; Pandey et al., in press; Tlili et al., 2011). This metric is not commonly used in bioassessment, although it has potential in contributing additional information on ecosystem health. The time required for valve measurements may be one limiting factor which makes cell-size metrics currently unpopular in biomonitoring studies. Studies also reported deformities or shape changes in diatom frustules as a result of size reduction (Hasle and Syvertsen, 1996).

Assessment of diatom health (live, unhealthy and dead cells) is also an interesting but unconventional descriptor to consider when assessing a response to contamination (Gillett et al., 2011; Morin et al., 2010; Pandey et al., in press; Stevenson and Pan, 1999). It however requires relatively early observations of the sample. This analysis of fresh material could be coupled with cell motility (Coquillé et al., 2015) and lifeform (or guild or trait) assessments. These biological descriptors, also not commonly used, have shown relationships with ecological conditions (e.g., Berthon et al., 2011; Passy, 2007; Rimet and Bouchez, 2011). The live and dead status assessment can also be coupled with teratology observations. For example, live and dead diatoms were differentiated at sites affected by metals and acid mine drainage, and the results showed a large amount of deformities and high percentage of dead diatoms ( $>15 \%$ ) (Manoylov, Phycology lab, Georgia College and State University, Georgia, USA; unpublished results).

The presence of lipid bodies or lipid droplets in diatoms can be a descriptor of ecosystem health. Lipid bodies are produced by all algae as food reserves, and can be stimulated under various conditions (d'Ippolito et al., 2015; Liang et al., 2015; Wang et al., 2009; Yang et al., 2013). This biomarker has shown good fit with contamination; lipid bodies increasing in number and size under metal contamination (Pandey et al., in press; Pandey and Bergey, 2016). Lipid analysis does not require taxonomic skills, and can be quantified using dyes and fluorescence. However, depending on the level of contamination, the cell may be excessively stressed and the lipid bodies could be oxidized in order to reduce the overproduction of reactive oxygen species (ROS) (as observed in the green alga Dunaliella salina, Yilancioglu et al., 2014). Moreover, lipid bodies are produced under many environmental conditions (e.g., lipids, more specifically triacyl glycerol (TAGs), increase under high bicarbonate levels; Mekhalfi et al., 2014), and the correlation with metal contamination may be subject to fluctuation.

Finally, antioxidant enzymes are also good biomarkers of stress (Regoli and Giuliani, 2013). Under stress conditions organisms suffer cellular alterations, such as overproduction of ROS, which can cause damage in lipids, proteins and DNA. Cells have defense mechanisms against ROS, and once they are activated, there are several biochemical markers to assess different contaminations. These classical tests, adapted to diatoms, are associated with the measurement of ROS scavenging enzymes or non-enzymatic processes such as production and oxidation of glutathione and phytochelatins, or measuring lipid peroxidation and pigments content. More studies are being developed to find specific biomarkers for toxicants in order to effectively assess their impact on diatoms (Branco et al., 2010; Corcoll et al., 2012; Guasch et al., 2016).

Considering the number of available diatom-based biological descriptors, we recommend the development of a multi-metric index for contamination assessment. Keeping in mind the limited time and resources available (money, analysts, equipment) it would not be reasonable to include all metrics. In the future, new technologies combining genetic, physiological and environmental measures may contribute to develop routine biomonitoring tools. As a first step to facilitate future bioassessments, a library of teratological metrics rated against environmental health will be required. Currently, the complementary information issued from the combination of certain selected metrics could significantly enhance the ecological information provided by diatoms, and therefore improve our understanding of ecosystems status. The assessment of contamination using biological descriptors could also be refined by combining the response of organisms from different trophic levels. For example, diatom-based metrics could be combined with invertebrate-teratology metrics such as chironomid larvae mouthpart deformities.

\section{Conclusions and perspectives}

Are teratologies alone sufficient to adequately assess a response to contamination? Is this biological descriptor ecologically meaningful? These are the fundamental questions of this discussion paper. The answer is undoubtedly yes with selected taxa based on the number of studies that were successful in correlating \% deformities and contamination (mostly metals and pesticides). However, taxa prone to shape deformities (e.g., Fragilaria, Eunotia) under natural conditions may provide a false positive in terms of a response to contamination and thus deformities in these taxa alone within a community should not be overinterpreted. Sharing current experiences and knowledge among colleagues has certainly raised numerous questions and underscores certain limitations in the approach. This paper provides various paths forward to refine our understanding of diatom teratologies, and hence, increase the sensitivity of this metric in bioassessments. Many suggestions were presented, and they all deserve more thorough consideration and investigation. One more opinion to share is that the occurrence of teratologies is a red flag for contamination, even though teratologies do not always correlate with the level of contamination. Teratologies, at the very least, are good "screening" indicators providing warnings that water quality measurements are needed at a site. This alone is interesting for water managers trying to save on unnecessary and costly analyses. Moreover, the general ecological signal provided could suggest the presence of a stressor that may affect other organisms, and ultimately ecosystem integrity and functions (ecosystem services). We anticipate that enumerating and identifying diatom deformities can 
become a routine part of agency protocols for environmental stress assessment. Most countries are required to comply with water quality regulations and guidelines that would greatly benefit from such a biomonitoring tool. Hopefully, this paper will trigger more discussion and research on the subject to enhance our understanding of the precious ecological information provided by the presence of diatom teratologies.

\section{Author contributions}

The first five authors contributed most significantly to the paper. The other co-authors, who collaborated to the work, are placed subsequently in alphabetical order.

\section{Acknowledgements}

C. Fortin and I. Lavoie acknowledge the financial support of the Fonds de recherche du Québec - Nature et technologies through the Développement durable du secteur minier programme. C. Fortin is supported by the Canada Research Chair programme. The contribution of S. Morin is through the framework of the Cluster of Excellence COTE (ANR-10-LABX-45). Funding for this work and curation of the National Phycology Collection (CANA) for P.B. Hamilton comes from the Canadian Museum of Nature (RAC 2014-2016). The contribution of M. Kahlert and S. Gonçalves is partly funded by SLU's Environmental monitoring and assessment (EMA) programme "Non-Toxic environment". M. Kahlert is also thankful for funding from The Swedish Agency for Marine and Water Management sub-programme "Diatoms". L.K. Pandey is supported by Incheon National University (International Cooperative Research Grant). J.C. Taylor is the recipient of South African National Research Foundation (NRF) incentive funding. Any opinions, findings and conclusions or recommendations expressed in this material are those of the author(s) and therefore the NRF does not accept any liability in regard thereto. The authors would like to thank Prof. G. Badino for helful discussion and comments on this paper.

\section{Appendix A. Supplementary data}

Supplementary data associated with this article can be found, in the online version, at http://dx.doi.org/10.1016/j.ecolind.2017.06.048.

\section{References}

Arini, A., Feurtet-Mazel, A., Morin, S., Maury-Brachet, R., Coste, M., Delmas, F., 2012. Remediation of a watershed contaminated by heavy metals: a 2-year field biomoni toring of periphytic biofilms. Sci. Total Environ. 425, 242-253.

Arini, A., Durant, F., Coste, M., Delmas, F., Feurtet-Mazel, A., 2013. Cadmium decontamination and reversal potential of teratological forms of the diatom Planothidium frequentissimum (Bacillariophyceae) after experimental contamination. J. Phycol. 49, 361-370.

Barber, H.G., Carter, J.R., 1981. Observations on some deformities found in British diatoms. Microscopy 3, 214-226.

Barral-Fraga, L., Morin, S., Rovira, M.D.M., Urrea, G., Magellan, G., Guasch, H., 2016. Short-term arsenic exposure reduces diatom cell size in biofilm communities. Environ. Sci. Pollut. Res. 23, 4257-4270.

Berthon, V., Bouchez, A., Rimet, F., 2011. Using diatom life-forms and ecological guilds to assess organic pollution and trophic level in rivers: a case study of rivers in SouthEastern France. Hydrobiologia 673, 259-271.

Blanck, H., Wängberg, S.A., Molander, S., 1988. Pollution-induced community tolerance - a new ecotoxicological tool. Cairns, J., Pratt, J.R. (Eds.), Functional Testing of Aquatic Biota for Estimating Hazards of Chemicals. ASTM, Philadelphia, pp. 219-230.

Blanco, S., Cejudo-Figueiras, C., Tudesque, L., Bécares, E., Hoffmann, L., Ector, L., 2012. Are diatom diversity indices reliable monitoring metrics? Hydrobiologia 695, 199-206.

Branco, D., Lima, A., Almeida, S.F., Figueira, E., 2010. Sensitivity of biochemical markers to evaluate cadmium stress in the freshwater diatom Nitzschia palea (Kützing) W. Smith. Aquat. Toxicol. 99, 109-117.

Cantonati, M., Angeli, N., Virtanen, L., Wojtal, A.Z., Gabriell, J., Falasco, E., Lavoie, I., Morin, S., Marchetoo, A., Fortin, C., Smirnova, S., 2014. Achnanthidium minutissimum (Bacillariophyta) valve deformities as indicators of metal enrichment in diverse widely-distributed freshwater habitats. Sci. Total Environ. 75, 201-215.

Cattaneo, A., Couillard, Y., Wunsam, S., Courcelles, M., 2004. Diatom taxonomic and morphological changes as indicators of metal pollution and recovery in Lac Dufault
(Québec, Canada). J. Paleolimnol. 32, 163-175.

Chepurnov, V.A., Mann, D.G., Sabbe, K., Vyverman, W., 2004. Experimental studies on sexual reproduction in diatoms. Int. Rev. Cytol. 237, 91-154.

Clements, W.H., Carlisle, D.M., Lazorchak, J.M., Johnson, P.C., 2000. Heavy metals structure benthic communities in Colorado mountain streams. Ecol. Appl. 10, 626-638.

Coquillé, N., Jan, G., Moreira, A., Morin, S., 2015. Use of diatom motility features as endpoints of metolachlor toxicity. Aquat. Toxicol. 158, 202-210.

Corcoll, N., Ricart, M., Franz, S., Sans-Piché, F., Schmitt-Jansen, M., Guasch, H., 2012 The use of photosynthetic fluorescence parameters from autotrophic biofilms for monitoring the effect of chemicals in river ecosystems. In: Guasch, H., Ginebreda, A., Geiszinger, A. (Eds.), Emerging and Priority Pollutants in Rivers. Hdb Env Chem., vol. 19. Springer, Berlin, Heidelberg, pp. 85-115.

Coste, Boutry, S., Tison-Rosebery, J., Delmas, F., 2009. Improvements of the Biological Diatom Index (BDI): Description and efficiency of the new version (BDI-2006). Ecol. Indic. 9, 621-650.

Cox, E.J., Willis, L., Bentley, K., 2012. Integrated simulation with experimentation is a powerful tool for understanding diatom valve morphogenesis. Biosystems 109 , 450-459.

Cox, J.D., 1890. Deformed diatoms. Proc. Am. Soc. Microscopists 12, 178-183.

Cox, E.J., 2012. Ontogeny, homology, and terminology-wall morphogenesis as an aid to character recognition and character state definition for pennate diatom systematics. J. Phycol. 48, 1-31.

Cremer, H., Wagner, B., 2004. Planktonic diatom communities in high arctic lakes (Store koldewey, northeast Greenland). Can. J. Bot. 82, 1744-1757.

Debenest, T., Silvestrea, J., Coste, M., Delmas, F., Pinelli, E., 2008. Herbicide effects on freshwater benthic diatoms: induction of nucleus alterations and silica cell wall abnormalities. Aquat. Toxicol. 88, 88-94.

Debenest, T., Silvestre, J., Coste, M., Pinelli, E., 2010. Effects of pesticides on freshwater diatoms. Whitacre, D.M. (Ed.), Reviews of Environmental Contamination and Toxicology. Springer, Berlin, pp. 87-103.

Drebes, G., 1966. On the life history of the marine plankton diatom Stephanopyxis palmeriana. Helgoland Mar. Res. 13, 101-114.

Duong, T.T., Morin, S., Herlory, O., Feurtet-Mazel, A., Coste, M., Boudou, A., 2008. Seasonal effects of cadmium accumulation in periphytic diatom communities of freshwater biofilms. Aquat. Toxicol. 90, 19-28.

Duong, T.T., Morin, S., Coste, M., Herlory, O., Feurtet-Mazel, A., Boudou, A., 2010. Experimental toxicity and bioaccumulation of cadmium in freshwater periphytic diatoms in relation with biofilm maturity. Sci. Total. Environ. 408, 552-562.

Estes, A., Dute, R.R., 1994. Valve abnormalities in diatom clones maintained in long-term culture. Diatom Res. 9, 249-258.

Falasco, E., Bona, F., Badino, G., Hoffmann, L., Ector, L., 2009a. Diatom teratological forms and environmental alterations: a review. Hydrobiologia 623, 1-35.

Falasco, E., Bona, F., Ginepro, M., Hlúbiková, D., Hoffmann, L., Ector, L., 2009b. Morphological abnormalities of diatom silica walls in relation to heavy metal contamination and artificial growth conditions. Water S. A. 35, 595-606.

Falasco E., 2009. The ecological meaning of diatom teratological forms induced by environmental stress. Ph.D. thesis of the Doctoral School of Science and High Technology - Plant and Environmental Biosensors XXI. 239 pp.

Fernández, M.R., Martín, G., Corzo, J., de la Linde, A., García, E., López, M., Sousa, M., 2017. Design and testing of a new diatom-based index for heavy metal pollution. Arch. Environ. Contam. Toxicol. http://dx.doi.org/10.1007/s00244-017-0409-6.

Gallagher, J.C., 1983. Cell enlargement in Skeletonema costatum (Bacillariophyceae). J. Phycol. 19, 539-542.

Gillett, N.D., Pan, Y., Manoylov, K.M., Stevenson, R.J., 2011. The role of live diatoms in bioassessment: a large-scale study of Western US streams. Hydrobiologia 665, 79-92.

Gold, C., Feurtet-Mazel, A., Coste, M., Boudou, A., 2002. Field transfer of periphytic diatom communities to assess short-term structural effects of metals (Cd, Zn) in rivers. Water Res. 36, 3654-3664.

Gold, C., Feurtet-Mazel, A., Coste, M., Boudou, A., 2003. Impacts of Cd and Zn on the development of periphytic diatom communities in artificial streams located along a river pollution gradient. Arch. Environ. Contam. Toxicol. 44, 189-197.

Gordon, R., Losic, D., Tiffany, M.A., Nagy, S.S., Sterrenburg, F.A., 2009. The glass menagerie: diatoms for novel applications in nanotechnology. Trends Biotechnol. 27, $116-127$.

Granetti, B., 1968. Alcune forme teratologiche comparse in colture di Navicula minima Grun. e Navicula seminulum Grun. Giorn. Bot. Ital. 102, 469-484.

Guasch, H., Artigas, J., Bonet, B., Bonnineau, C., Canals, O., Corcoll, N., Foulquier, A., López-Doval, J., Kim Tiam, S., Morin, S., et al., 2016. The use of biofilms to assess the effects of chemicals on freshwater ecosystems. Romaní, A.M., Guasch, H., Balaguer, M.D. (Eds.), Aquatic Biofilms: Ecology, Water Quality and Wastewater Treatment. Caister Academic Press, pp. 126-144.

Hasle, G.R., Syvertsen, E.E., 1996. Marine diatoms. Tomas, C.R. (Ed.), Identifying Marine Diatoms and Dinoflagellates. Academic Press, San Diego, pp. 5-385.

Huber-Pestalozzi, G., 1946. Der Walensee und sein plankton. Z. Hydrol. 10, 1-200.

Hustedt, F., 1956. Kieselalgen (Diatomeen). Einführung in Die Kleinlebwelt. Kosmos Verlag, Stuttgart (70 p.).

Ivorra, N., Hettelaar, J., Tubbing, G.M.J., Kraak, M.H.S., Sabater, S., Admiraal, W., 1999. Translocation of microbenthic algal assemblages used for in situ analysis of metal pollution in rivers. Arch. Environ. Contam. Toxicol. 37, 19-28.

Jüttner, I., Ector, L., Reichardt, E., Van de Vijver, B., Jarlman, A., Krokowski, J., Cox, E.J., 2013. Gomphonema varioreduncum sp. nov., a new species from northern and western Europe and a re-examination of Gomphonema exilissimum. Diatom Res. 28, 303-316.

Kahlert, M., 2012. Utveckling av en miljögiftsindikator - kiselalger i rinnande vatten. Rapport Länsstyrelsen Blekinge 12 (40 pp.).

Knight, M.J., Senior, L., Nancolas, B., Ratcliffe, S., Curnow, P., 2016. Direct evidence of 
the molecular basis for biological silicon transport. Nat. Commun. 7, 11926.

Kröger, N., Poulsen, N., 2008. Diatoms-from cell wall biogenesis to nanotechnology. Annu. Rev. Genet. 42, 83-107.

Kröger, N., Bergsdorf, C., Sumper, M., 1994. A new calcium binding glycoprotein family constitutes a major diatom cell wall component. EMBO J. 13, 4676-4683.

Kröger, N., Bergsdorf, C., Sumper, M., 1996. Frustulins: domain conservation in a protein family associated with diatom cell walls. Eur. J. Biochem. 239, 259-264.

Kröger, N., Lehmann, G., Rachel, R., Sumper, M., 1997. Characterization of a 200-kDa diatom protein that is specifically associated with a silica-based substructure of the cell wall. Eur. J. Biochem. 250, 99-105.

Lainé, M., Morin, S., Tison-Rosebery, J., 2014. A multicompartment approach ? diatoms, macrophy. PLoS One 9, e102358.

Lavoie, I., Grenier, M., Campeau, S., Dillon, P.J., 2006. A diatom-based index for water quality assessment in eastern Canada: an application of canonical analysis. Can. J. Fish. Aquat. Sci. 63, 1793-1811.

Lavoie, I., Lavoie, M., Fortin, C., 2012. A mine of information: benthic algal communities as biomonitors of metal contamination from abandoned tailings. Sci. Total Environ. 425, 231-241.

Lavoie, I., Campeau, S., Zugic-Drakulic, N., Winter, J.G., Fortin, C., 2014. Using diatoms to monitor stream biological integrity in eastern Canada: an overview of 10 years of index development and ongoing challenges. Sci. Total Environ. 475, 187-200.

Leguay, S., Lavoie, I., Levy, J.L., Fortin, C., 2016. Using biofilms for monitoring metal contamination in lotic ecosystems: the protective effects of hardness and $\mathrm{pH}$ on metal bioaccumulation. Environ. Toxicol. Chem. 35, 1489-1501.

Liang, Y., Osada, K., Sunaga, Y., Yoshino, T., Bowler, C., Tanaka, T., 2015. Dynamic oil body generation in the marine oleaginous diatom Fistulifera solaris in response to nutrient limitation as revealed by morphological and lipidomic analysis. Algal Res. $12,359-367$.

Licursi, L., Gomez, N., 2013. Short-term toxicity of hexavalent-chromium to epipsammic diatoms of a microtidal estuary (Riode la Plata): Responses from the individual cell to the community. Aquat. Toxicol 134-135, 82-91.

d'Ippolito, G., Sardo, A., Paris, D., Vella, F.M., Adelfi, M.G., Botte, P., Gallo, C., Fontana, A., 2015. Potential of lipid metabolism in marine diatoms for biofuel production. Biotechnol. Biofuels 8, 1-10.

Luís, A.T., Teixeira, P., Almeida, S.F.P., Matos, J.X., da Silva, E.F., 2011. Environmental impact of mining activities in the Lousal area (Portugal): chemical and diatom characterization of metal-contaminated stream sediments and surface water of Corona stream. Sci. Total Environ. 409, 4312-4325.

Mann, D.G., 1981. A note on valve formation and homology in the diatom genus Cymbella. Ann. Bot. 47, 267-269.

Mann, D.G., 1982. Auxospore formation in Licmophora (Bacillariophyta). Plant Syst. Evol. 139, 289-294.

Mann, D.G., 1986. Methods of sexual reproduction in Nitzschia: systematic and evolutionary implications (Notes for a monograph of the Bacillariaceae 3). Diatom Res. 1, 193-203.

Mekhalfi, M., Amara, S., Robert, S., Carriere, F., Gontero, B., 2014. Effect of environmental conditions on various enzyme activities and triacylglycerol contents in cultures of the freshwater diatom, Asterionella formosa (Bacillariophyceae). Biochimie $101,21-30$.

Morin, S., Duong, T.T., Dabrin, A., Coynel, A., Herlory, O., Baudrimont, M., Delmas, F. Durrieu, G., Schäfer, J., Winterton, P., Blanc, G., Coste, M., 2008a. Long-term survey of heavy-metal pollution, biofilm contamination and diatom community structure in the Riou Mort watershed, South-West France. Environ. Pollut. 115, 532-542.

Morin, S., Duong, T.T., Herlory, O., Feurtet-Mazel, A., Coste, M., 2008b. Cadmium toxicity and bioaccumulation in freshwater biofilms. Arch. Environ. Contam. Toxicol. 54, $173-186$

Morin, S., Coste, M., Hamilton, P.B., 2008c. Scanning electron microscopy (SEM) observations of deformities in small pennate diatoms exposed to high cadmium con centrations. J. Phycol. 44, 1512-1518.

Morin, S., Cordonier, A., Lavoie, I., Arini, A., Blanco, S., Duong, T.T., Tornés, E., Bonet, B., Corcoll, N., Faggiano, L., Laviale, M., Pérès, F., Becares, E., Coste, M., Feurtet-Mazel, A., Fortin, C., Guasch, H., Sabater, S., 2012. Consistency in diatom response to metalcontaminated environments. In: Guasch, H., Ginebreda Geiszinger, A.A. (Eds.), Emerging and Priority Pollutants in Rivers. Hdb Env Chem., vol. 19. Springer, Heidelberg, pp. 117-146.

Morin, S., Corcoll, N., Bonet, B., Tlili, A., Guasch, H., 2014. Diatom responses to zinc contamination along a Mediterranean river. Plant Ecol. Evol. 147, 325-332.

Morin, S., Proia, L., Ricart, M., Bonnineau, C., Geiszinger, A., Ricciardi, F., Guasch, H., Romaní, A., Sabater, S., 2010. Effects of a bactericide on the structure and survival of benthic diatom communities. Vie et Milieu (Life and Environment) 60, 109-116.

Pandey, L.K., Kumar, D., Yadav, A., Rai, J., Gaur, J.P., 2014. Morphological abnormalities in periphytic diatoms as a tool for biomonitoring of heavy metal pollution in a river. Ecol. Indic. 36, 272-279.

Pandey, L.K., Han, T., Gaur, J.P., 2015. Response of a phytoplanktonic assemblage to copper and zinc enrichment in microcosm. Ecotoxicology 24, 573-582.
Pandey L.K., Lavoie I., Morin S., Park J., Jie L., Choi S., Lee H., Han. T., River water quality assessment based on a multi-descriptor approach including chemistry, diatom assemblage structure, and non-taxonomical diatom metrics. Ecol. Indic. (in press)

Pandey, L.K., Bergey, E.A., 2016. Exploring the status of motility, lipid bodies, deformities and size reduction in periphytic diatom community from chronically metal $(\mathrm{Cu}, \mathrm{Zn})$ polluted waterbodies as a biomonitoring tool. Sci. Total Environ. 550, 372-381.

Passy, S.I., 2007. Differential cell size optimization strategies produce distinct diatom richness-body size relationships in stream benthos and plankton. J. Ecol. 95, 745-754.

Pickett-Heaps, J.D., Tippit, D.H., Andreozzi, J.A., 1979. Cell division in the pennate diatom Pinnularia. IV. Valve morphogenesis. Biol. Cell 35, 199-203.

Pickett-Heaps, J.D., Schmid, A.-M.M., Edgar, L.A., 1990. The cell biology of diatom valve formation. In: Round, F.E., Chapman, D.J. (Eds.), Progress in Phycological Research, vol. 7. Biopress Ltd., Bristol, pp. 1-168.

Regoli, F., Giuliani, M.E., 2013. Oxidative pathways of chemical toxicity and oxidative stress biomarkers in marine organisms. Mar. Environ. Res. 1136, 121-129.

Rimet, F., Bouchez, A., 2011. Use of diatom life-forms and ecological guilds to assess pesticide contamination in rivers: lotic mesocosm approaches. Ecol. Indic. 11, 489-499.

Roubeix, V., Mazzella, N., Méchin, B., Coste, M., Delmas, F., 2011. Impact of the herbicide metolachlor on river periphytic diatoms: experimental comparison of descriptors at different biological organization levels. Ann. Limnol.-Int. J. Limnol. 47, 1-11.

Roubeix, V., Pesce, S., Mazzella, N., Coste, M., Delmas, F., 2012. Variations in periphytic diatom tolerance to agricultural pesticides in a contaminated river: an analysis at different diversity levels. Fresenius Environ. Bull. 21, 2090-2094.

Round, F.E., Crawford, R.M., Mann, D.G., 1990. The Diatoms - Biology and Morphology of the Genera. Cambridge University Press (747 pp.).

Sabbe, K., Chepurnov, V.A., Vyverman, W., Mann, D.G., 2004. Apomixis in Achnanthes (Bacillariophyceae); development of a model system for diatom reproductive biology. Eur. J. Phycol. 39, 327-341.

Santos, J., Almeida, S.F., Figueira, E., 2013. Cadmium chelation by frustulins: a novel metal tolerance mechanism in Nitzschia palea (Kützing) W. Smith. Ecotoxicology 22, $166-173$.

Sato, S., Mann, D.G., Nagumo, T., Tanaka, J., Tadano, T., Medlin, L.K., 2008. Auxospore fine structure and variation in modes of cell size changes in Grammatophora marina (Bacillariophyta). Phycologia 47, 12-27.

Sato, S., Watanabe, T., Nagumo, T., Tanaka, J., 2011. Valve morphogenesis in an araphid diatom Rhaphoneis amphiceros (Rhaphoneidaceae, Bacillariophyta). Phycol. Res. 59, 236-243.

Schmid, A.-M.M., Schulz, D., 1979. Wall morphogenesis in diatoms: deposition of silica by cytoplasmic vesicles. Protoplasma 100, 267-288.

Schmid, A.M.M., 1980. Valve morphogenesis in diatoms: a pattern-related filamentous system in pennates and the effect of APM, colchicine and osmotic pressure. Nova Hedwigia 33, 811-847.

Sgro, G.V., Poole, J.B., Johansen, J.R., 2007. Diatom species composition and ecology of the Animas River Watershed, Colorado, USA. Western N. Am. Nat. 67, 510-519.

Smol, J.P., Stoermer, E.F., 2010. The Diatoms. Applications for the Environmental and Earth Sciences, second edition. Cambridge University Press, UK (667 pp.).

Stevenson, R.J., Pan, Y., 1999. Assessing environmental conditions in rivers and streams with diatoms. Stoermer, E.F., Smol, J.P. (Eds.), The Diatoms. Applications for the Environmental and Earth Sciences. Cambridge University Press, pp. 11-40.

Stoermer, E.F., 1967. Polymorphism in mastogloia. J. Phycol. 3, 73-77.

Stoermer, E.F., Andresen, N.A., 2006. Atypical Tabularia incoastal Lake erie, USA Ognjanova-Rumenova, N., Manoylov, K.M. (Eds.), Fossil and Recent Phycological Studies. Pensoft Publishers, Moscow, pp. 9-16.

Tlili, A., Corcoll, N., Bonet, B., Morin, S., Montuelle, B., Bérard, A., Guasch, H., 2011. In situ spatio-temporal changes in pollution-induced community tolerance to zinc in autotrophic and heterotrophic biofilm communities. Ecotoxicology 20, 1823-1839.

Toyoda, K., Idei, M., Nagumo, T., Tanaka, J., 2005. Fine structure of the vegetative frustule, perizonium and initial valve of Achnanthes yaquinensis (Bacillariophyta). Eur. J. Phycol. 40, 269-279.

von Stosch, H.A., 1982. On auxospore envelopes in diatoms. Bacillaria 5, 127-156.

Wang, Z.T., Ullrich, N., Joo, S., Waffenschmidt, S., Goodenough, U., 2009. Algal lipid bodies: stress induction, purification and biochemical characterization in wild-type and starchless Chlamydomonas reinhardtii. Eukaryot. Cell 8, 1856-1868.

Williams, D.M., 2001. Comments on the structure of 'postauxospore' valves of Fragilariforma virescens. Jahn, R., Kociolek, J.P., Witkowski, A., Compère, P. (Eds.), Lange-Bertalot Festschrift, Studies on Diatoms. A.R.G. Gantner, Ruggell, Liechtenstein, pp. 103-117.

Yang, Z.K., Niu, Y.F., Ma, Y.H., Xue, J., Zhang, M.H., Yang, W.D., Liu, J.S., Lu, S.H., Guan, Y., Li, H.Y., 2013. Molecular and cellular mechanisms of neutral lipid accumulation in diatom following nitrogen deprivation. Biotechnol. Biofuels 6, 67.

Yilancioglu, K., Cokol, M., Pastirmaci, I., Erman, B., Cetiner, S., 2014. Oxidative stress is a mediator for increased lipid accumulation in a newly isolated Dunaliella salina strain. PLoS One 9 (3), e91957. http://dx.doi.org/10.1371/journal.pone.0091957. 